\title{
交直ハイブリッド電解法により構造制御したポーラスアルミナを テンプレートとしたニッケルナノピラーの作製
}

\author{
服部 貴則 ${ }^{\mathrm{a}}$, 有山 雄介 ${ }^{\mathrm{a}}$, 藤野 隆由 ${ }^{\mathrm{a},}{ }^{*}$, 伊藤 征司郎 ${ }^{\mathrm{a}}$ \\ a 近畿大学 理工学部 ( ₹ 577-8502 大阪府東大阪市小若江 3-4-1)
}

\section{Preparation of Nickel Nanopillars Using Structure-Controlled Porous Anodized Aluminum by Hybrid Electrolysis of AC and DC}

\author{
Takanori HATTORI a , Yusuke ARIYAMA ${ }^{\text {a }}$, Takayoshi FUJINO ${ }^{\text {a, }}$ and Seishiro ITO ${ }^{\text {a }}$ \\ ${ }^{a}$ Faculty of Science and Engineering, Kinki University (3-4-1, Kowakae, Higashiosaka-shi, Osaka 577-8502)
}

\begin{abstract}
Aluminum was anodized in an oxalic acid bath using AC and DC hybrid electrolysis at a frequency of $0.1-1000 \mathrm{~Hz}$ and with DC galvanostatic electrolysis. Palladium was electrodeposited as a catalyst into pores of the anodized films using AC potentiostatic electrolysis. Electroplating was prepared continuously on anodized films of aluminum. Then the anodized film was dissolved in $5 \mathrm{~mol} \mathrm{dm}^{-3} \mathrm{NaOH}$ aqueous solution at room temperature to obtain nickel nanopillar aggregate (about 50-90 $\mathrm{nm}$ diameter).

Results of SEM evaluation showed that the pore diameter and number (structure) of anodized films were governed by the impressed frequency. The frequency and the pore diameter showed an inverse relation. In addition, nickel nanopillars were prepared from an anodized film template. Results show that the pillar diameter accorded with the pore diameter of the anodized film.
\end{abstract}

Keywords : Nanopillars, Porous Aluminum, Anodized Films

\section{1. 緒 言}

近年，ナノチューブ，ナノワイヤおよびナノピラーなどの ナノ構造物が持つ特有の現象を利用し, 光デバイスやセンサ, 光学レンズ, 電極などへの応用研究が盛んに行われてい

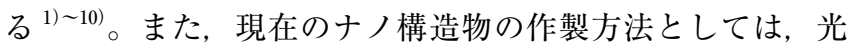
や電子線によりパターニングを行うリソグラフィー法やゾル

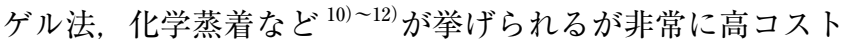
であり，比較的ピラー径も大きくサブミクロンオーダーとい う問題点がある。そのため, これらに代わる低コストかつ形 状や構造の制御が容易な作製方法の開発が求められている。

一方，アルミニウムをアノード酸化することによって得ら れる酸化皮膜は, 多孔質層を有し ${ }^{13)}$, その孔径や膜厚は, 電解条件や浴組成などに依存する。この多孔質皮膜は, 耐久 性や耐食性の向上，電解着色や染色による装飾性の向上，強 磁性体の電析 ${ }^{14)}$ や光触媒材 ${ }^{15)} に よ る$ 機能性の付加, ナノ チューブやナノワイヤのテンプレートなどに幅広く利用され ており, その特性は孔径や孔数といった皮膜の構造により変 化すると予想される。そこで, 本研究では, 交直重睍法とパ ルス電解法を複合させた新規な電解法である, 交直ハイブ リッド電解法 ${ }^{16)}$ によりアルミニウムアノード酸化膜の表面 構造を制御し，さらに，それらをテンプレートとした金属ナ ノピラー集合体の作製と細孔径構造制御を目的とした。

\section{2. 実験方法}

\section{1 アルミニウムアノード酸化膜の作製}

組成比 1:4 の過塩素酸とエ夕ノール混合溶液中で電解研磨 した純アルミニウム板（純度 $99.99 \% ， 30 \times 70 \times 0.4 \mathrm{~mm}$ )を， $0.5 \mathrm{~mol} \mathrm{dm}^{-3}$ しゅう酸浴中において, 定電流電解または交直 ハイブリッド電解を 5 分間行い, アノード酸化膜を作製した。 なお, 定電流電解における電解条件を電流密度 $1.0 \mathrm{~A} \mathrm{dm}^{-2}$, 交直ハイブリッド電解における電解条件は基底電流密度 $1.0 \mathrm{~A} \mathrm{dm}^{-2}$, 振幅 $1.0 \mathrm{~A} \mathrm{dm}^{-2}$, 周波数 $0.1 \sim 1000 \mathrm{~Hz}$, 電流波 形を矩形波とした。また, 電解時の電圧挙動については, オ シロスコープ(岩崎計測(株)製，DS-5102)を用いて測定した。

\section{2 孔径拡大処理}

アノード酸化膜は次のように孔径拡大処理を行った。この 操作は，長時間の浸漬による皮膜構造の破壊を防ぐため，ま ず, $0.1 \mathrm{~mol} \mathrm{dm}^{-3}$ クロム酸を含む $1.0 \mathrm{~mol} \mathrm{dm}{ }^{-3}$ りん酸混合溶 液中で 10 分間浸漬させた。その後, 溶解したセル壁を整形 するため, 再度 $1.0 \mathrm{~mol} \mathrm{dm}{ }^{-3}$ しゅう酸浴中において, 電流密 度 $1.0 \mathrm{~A} \mathrm{dm}^{-2}$ で 1 分間の定電流アノード酸化を行い, これら を 5 回ずつ繰り返すことで孔径拡大処理とした。

\section{3 ニッケルナノピラー集合体の作製}

2. 3. 1 パラジウム電析

得られたアノード酸化膜に対し，塩酸で $\mathrm{pH}$ を 0.5 に調整 した塩化パラジウム浴中において，対極に白金板を用い，定 電圧 $7 \mathrm{~V}$ で 2 分間の交流電解を行った。

\footnotetext{
*E-mail : taka-f@apch.kindai.ac.jp
} 
2. 3. 2 ニッケル電解めっき

アノード酸化膜に対し, $0.9 \mathrm{~mol} \mathrm{dm}^{-3}$ 硫酸ニッケル, $0.2 \mathrm{~mol}$ $\mathrm{dm}^{-3}$ 塩化ニッケルおよび $0.6 \mathrm{~mol} \mathrm{dm}{ }^{-3}$ ほう酸の混合浴中に おいて, 対極にニッケル板を用い, 定電圧 $3 \mathrm{~V}$ で 30 分間の 電解ニッケルめっきを行った。

2. 3.3 ニッケルナノピラーの剥離

アノード酸化膜上に作製しためっき皮膜を, $5 \mathrm{~mol} \mathrm{dm}^{-3}$ 水 酸化ナトリウム水溶液中に浸漬し, アノード酸化膜を溶解さ せ, ニッケルナノピラー集合体を得た。

\section{3.4 走査型電子顕微鏡 $(\mathrm{SEM})$ による観察}

テンプレートとなるアノード酸化膜および得られたニッケ ルナノピラー集合体の SEM（日立製作所(株)製，S-4800）観察 を行った。なお,アノード酸化膜に対しては, オスミウムコー ター(株)真空デバイス製，HPC - 30)を用い，オスミウムを 約 $5 \mathrm{~nm}$ 試料表面に蒸着した。

2. 3.5 紫外一可視拡散反射スペクトル (UV/vis) 測定

ニッケルナノピラー集合体およびニッケル板の紫外－可視 拡散反射スペクトルを分光光度計（日立製作所(株)製 U-3900H） によって測定した。測定範囲は，200〜800 nm とした。

2. 3. 6 サイクリックボルタンメトリー $(\mathrm{CV})$ 測定

ニッケルナノピラー集合体の電極特性を, CVにより評価 した。ニッケルナノピラー集合体をセルに固定したものを作 用極 $(\mathrm{WE})$ とし, 対極に白金板 $(\mathrm{CE})$, 参照電極 $(\mathrm{RE})$ にカロ メル電極(S.C.E) を用いた。これらの 3 電極を $0.5 \mathrm{~mol} \mathrm{dm}^{-3}$ $\mathrm{Na}_{2} \mathrm{SO}_{4}$ および $5 \times 10^{-3} \mathrm{~mol} \mathrm{dm}^{-3} \mathrm{~K}_{3}\left[\mathrm{Fe}(\mathrm{CN})_{6}\right]$ の混合溶液に 挿入し, 電気化学測定装置 (SOLARTRON 製 $1280 \mathrm{ZT}$ ) を用い て測定した。測定条件は, 測定範囲を一 $300 \mathrm{mV}$ $+1000 \mathrm{mV}$, 掃引速度を $50 \sim 300 \mathrm{mV} \mathrm{s}^{-1}$, 掃引回数を 10 回 とした。測定時の回路図を図 1 に示した。

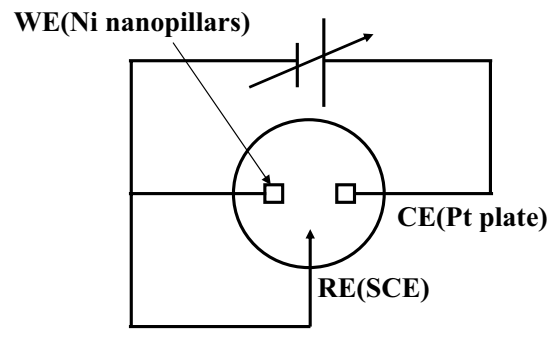

Fig. 1 Circuit diagram for cyclic voltammetry analysis.

\section{3. 結果および考察}

\section{1 アノード酸化膜の作製}

3. 1.1 交直ハイブリッド電解時における電圧の挙動 交直ハイブリッド電解時における電圧挙動をオシロスコー プにより測定した結果を図 2 に示した。a) は周波数 $0.1 \mathrm{~Hz}, \mathrm{~b}$ ) は $1000 \mathrm{~Hz}$ のときの電圧挙動である。その結果, 高周波数に なるにしたがい, 平均電圧が減少し, $1000 \mathrm{~Hz}$ のとき, 電流 および電圧の波形が崩れていることが確認された。これは, 水溶液中のカチオンやアニオンのイオン電導が周波数に追従 できないためと考えられる。周波数を印加して交直ハイブ リッドアノード酸化を行うとき, 得られる皮膜の容量キャパ シタンス $\left(X_{\mathrm{c}}\right)$ は次式 $(1)$ と (2)より求められる ${ }^{17)}$ 。

$$
\begin{aligned}
& \boldsymbol{X}_{\mathrm{c}}=\frac{1}{2 \pi \mathrm{fC}} \\
& \boldsymbol{V}=\boldsymbol{X}_{\mathrm{c}} \boldsymbol{I} \cdots \cdots
\end{aligned}
$$

$\mathrm{f}$ は周波数, $\mathrm{C}$ は電気容量である。式(1)より, 周波数が大 きくなるにしたがって皮膜の $X_{\mathrm{c}}$ が小さくなることがわかる。 また， $X_{\mathrm{c}}$ はオームの法則にしたがい式 $(2)$ で求めることがで きる。同じ電流密度でアノード酸化する場合, $X_{\mathrm{c}}$ の低下は,
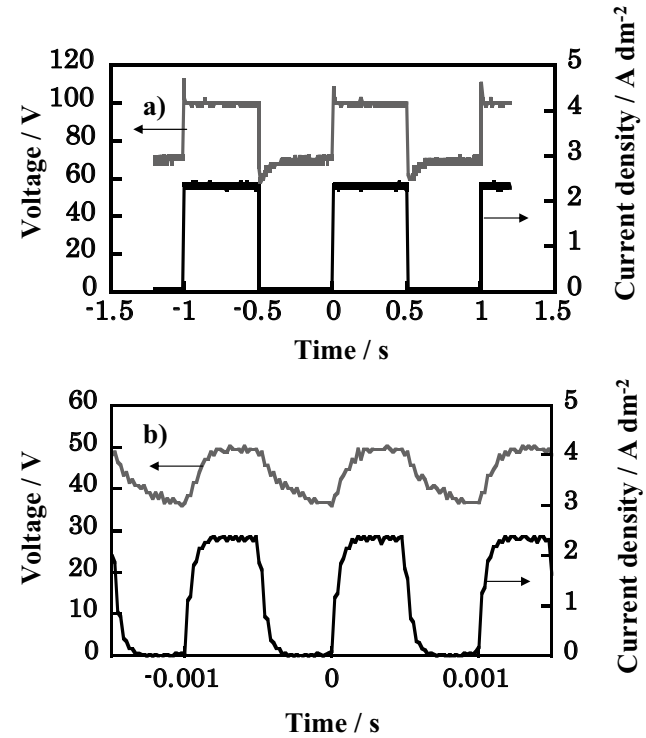

Fig. 2 Waveforms of current density and voltage in hybrid electrolysis of $\mathrm{AC}$ and $\mathrm{DC}$ under square wave; a) $0.1 \mathrm{~Hz}$-hybrid electrolysis of AC and DC; b) $1000 \mathrm{~Hz}$-hybrid electrolysis of AC and DC.
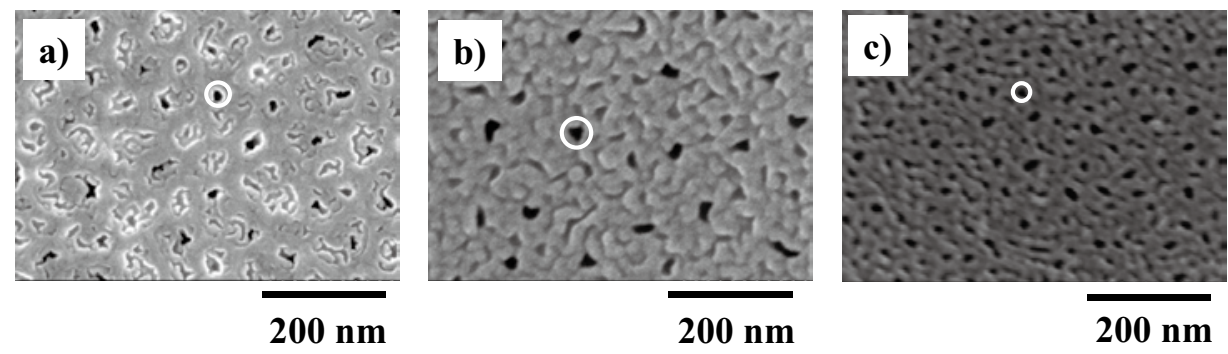

Fig. 3 SEM images of anodized film of aluminum; a) DC galvanostatic electrolysis; b) $0.1 \mathrm{~Hz}$-hybrid electrolysis of AC and DC; c) $1000 \mathrm{~Hz}$ - hybrid electrolysis of AC and DC. 
すなわち電圧の低下を意味し，オシロスコープによる観測結 果と一致する。平均電圧を比較すると, $0.1 \mathrm{~Hz}$ のとき約 $85 \mathrm{~V}$ であったが, $1000 \mathrm{~Hz}$ では約 $42 \mathrm{~V}$ となり, その差は $43 \mathrm{~V}$ となった。

\section{1. 2 SEM 観察結果}

周波数別に作製したアノード酸化膜のSEM 観察結果を図 3 に示した。a）は直流定電流電解，b）は $0.1 \mathrm{~Hz}$, c) は $1000 \mathrm{~Hz}$ の皮膜 SEM 写真である。周波数を変化させること により, 孔径や孔密度が顕著に変化していることが認められ た。また, セル間に溝が認められた。これは, 電解初期に形 成されたものであり, 七ル同士の境界であると考えられる。 さらに，1000 Hzで得られた皮膜においては，孔同士が結合 している部分も認められた。これは，図２に示したように， 浴電圧が低いため，セル壁が薄くなることによると考えられ る。次に, 周波数と孔径および周波数と孔数の関係を図 4 お よび図 5 に示した。図 4-a) は孔径拡大処理後, b) は孔径拡 大処理前の孔径変化をプロットしたものである。また, 図中 の破線は, 直流定電流電解から得られた皮膜の孔径を示して いる。孔の形状が均一ではないことを考慮して, 図 3 で示し た白円に囲まれた細孔の短径および長径を 5 点ずつ測定し,
最大值と最小值を除き, 平均值を孔径とした。さらに, 孔径 のばらつきを求め, 図 4 中に示した。なお, 先述のセル間の 溝や結合した孔は含まないものとした。印加する周波数に よってアノード酸化膜の孔径や孔数が変化しているのがわか る。これは, 周波数によって電解中の電圧が上下し, それに したがって孔壁厚さが変化すると考えられる。上式(1)およ び(2)から高周波印加時は電圧が低下し, 低周波印加時は電 圧が上昇する。いずれの結果も反比例の関係にあるので，低 周波になるにしたがってアノード酸化膜の孔径が大きくなっ たと考えられる。また, 孔数も同様に, 電圧と反比例の関係 にあるので，周波数の上昇とともに増加したと考えられる。 また，孔径拡大処理を施すことによって，アノード酸化膜の 孔径が約 $50 \mathrm{~nm}$ 大きくなることが確認でき, 高周波数になる ほど孔径が小さくなっていくことがわかった。

\section{2 ニッケルナノピラー集合体の作製}

図 6 にニッケルナノピラー集合体の作製における概略図を 示した。アノード酸化膜をりん酸 - クロム酸混合溶液に浸漬 し，図 6 に示した破線部分までセルを溶解することで，孔径 が拡大したアノード酸化膜が得られた $(\mathrm{a})$ 。次に, 得られた 皮膜に対し，ニッケルめっきを行い，アノード酸化膜を水酸

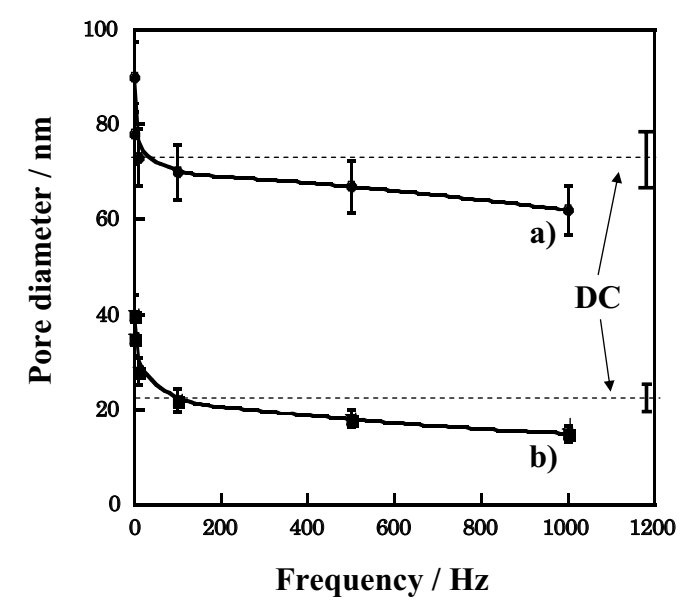

Fig. 4 Plots for pore diameter and number of pore vs. impressed frequency in anodization; a) with pore expansion; b) without pore expansion.

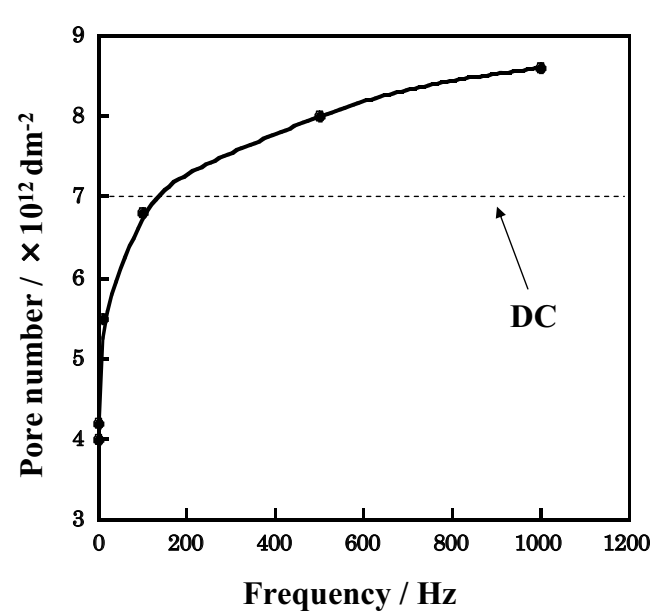

Fig. 5 Plots for number of pore vs. impressed frequency in anodization. a)

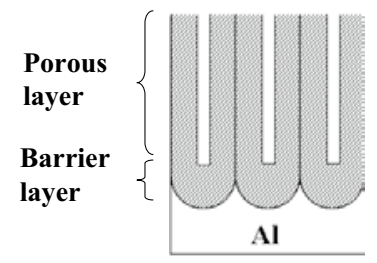

Porous anodized film

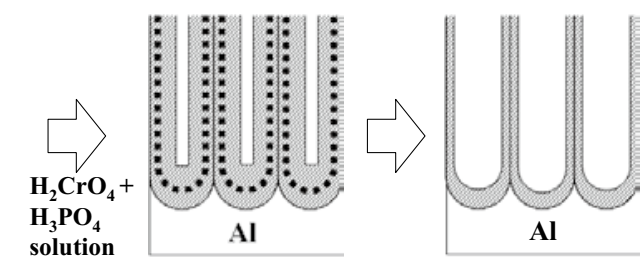

Al

b)
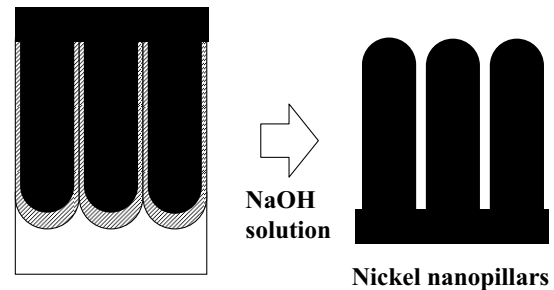

Fig. 6 Scheme for a) pore-widening and b) preparation of nickel nanopillars. 
化ナトリウム水溶液で溶解することによって, ニッケルナノ ピラー集合体が得られた $(b)$ 。電析したニッケルは, アノー ド酸化膜の細孔中に充填されるため, ナノピラー長さは, ア ノード酸化膜の膜厚に依存すると考えられる。また, アノー ド酸化皮膜は表面に近いほど優先的に溶解するため, 得られ るナノピラーの形状は真っ直ぐな円柱ではなく, 円錐に近い ものになると考えられる。しかしながら, ナノピラーのアス ペクト比が大きい場合, 破断あるいは凝集などが起こること が考えられるが，ピラー径を $100 〜 200 \mathrm{~nm}$ 以上に拡大する ことによって抑制できると予想される。

得られたニッケルナノピラー集合体の SEM 写真を図 7 に 示した。a) は直流定電流電解, b) は $0.1 \mathrm{~Hz}$, c) は $1000 \mathrm{~Hz}$ の アノード酸化皮膜をテンプレートとしたナノピラーの SEM 写真である。なお，ピラー長は約 $1 \mu \mathrm{m}$ であった。これらの 結果より, 各ナノピラー集合体 $1 \mathrm{~cm}^{2}$ 当たりの表面積は $1000 \mathrm{~Hz}$ : 約 $114 \mathrm{~cm}^{2}, 0.1 \mathrm{~Hz}$ : 約 $91 \mathrm{~cm}^{2}$, 直流定電流電解 : 約 $99 \mathrm{~cm}^{2}$ となることがわかった。また，ピラー面に針状の 物質が認められたが, これはアノード酸化膜が完全に溶解で きてないためか, あるいは洗浄が不十分であったものと考え られる。さらに, 図 8 に周波数とピラー径の関係を示した。 なお, 図中の破線は, 直流定電流電解皮膜から得られたナノ ピラーの直径を示している。また, 孔径のばらつきを求め, 図 8 中に示した。交直ハイブリッド電解法により, 周波数 $(<100 \mathrm{~Hz})$ の時に得られた皮膜を基板とした時のピラー径は,
定電流電解で作製したものよりも大きくなり, $100 \mathrm{~Hz}$ 以上 の周波数で得られたピラー径は小さくなることがわかった。 この傾向は, 図 4 に示したアノード酸化皮膜の孔径に対する 周波数依存性と良く一致しているといえる。

\section{3. $3 \mathrm{UV} / \mathrm{vis}$ スペクトル測定結果}

ニッケルナノピラー集合体の UV/vis スペクトル測定結果 を図 9 に示した。a) はニッケル平板, b) はニッケルナノピ ラーを用いることにより得られた UV/vis スペクトルである。 ニッケルナノピラーは, ニッケル平板とは違い電解着色皮膜 のような黒色であり，UV/vis スペクトル測定においても全 波長領域で光を吸収および散乱していることが確認できた。 これは, ナノピラー面の Rayleigh 散乱によるものであり, 表 面がアノード酸化膜の構造に基づくナノ構造を有するために, 紫外および可視領域の光を吸収・散乱するためと考えられる。

\section{3. $4 \mathrm{CV}$ 測定結果}

図 10 に，掃引速度を 50 〜 $300 \mathrm{mV} \mathrm{s}^{-1}$ まで変化させたサ イクリックボルタモグラムを示した。a）はニッケル平板，b） は $1000 \mathrm{~Hz}$ で得られたナノピラーを作用極として得られた $\mathrm{CV}$ 測定結果である。さらに, 図 11 に掃引速度を $100 \mathrm{mV} \mathrm{s}^{-1}$ に固定したサイクリックボルタモグラムを示した。a）は $1000 \mathrm{~Hz}$, b) は直流定電流電解, c) は $0.1 \mathrm{~Hz}$ で得られたナノ ピラー, d) はニッケル平板を作用極として得られた CV 測定 結果である。ナノピラーを電極とした時のピーク電流は, ニッ ケル平板に比べて約 80 倍と高い值を示した。しかし，SEM

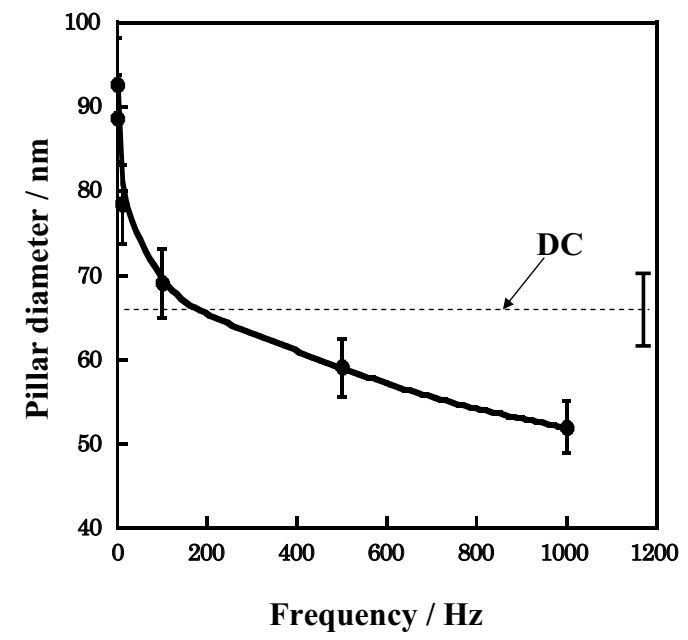

Fig. 8 Plots for pillar diameter vs. impressed frequency in anodization.

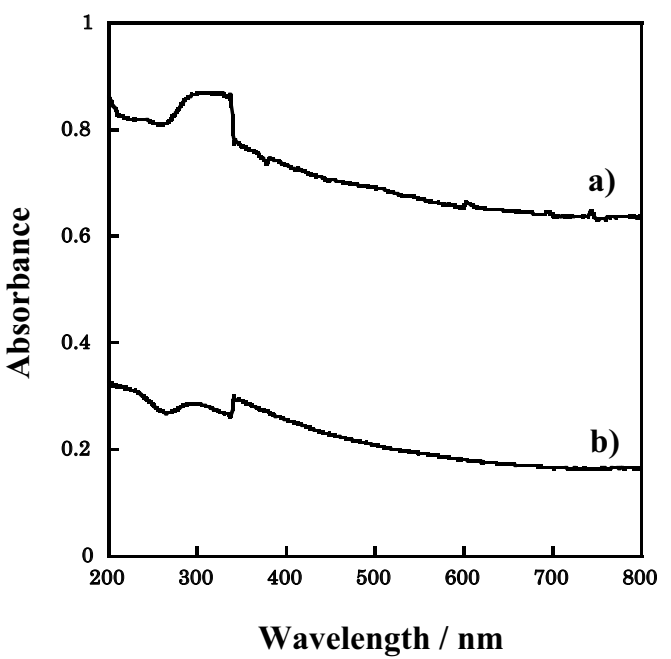

Fig. 9 UV/vis spectrum of a) nickel nanopillars; b) flat nickel plate.

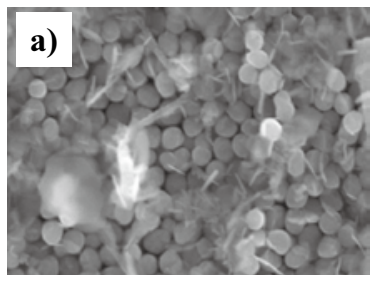

$500 \mathrm{~nm}$

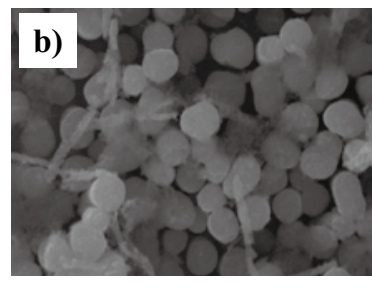

$500 \mathrm{~nm}$

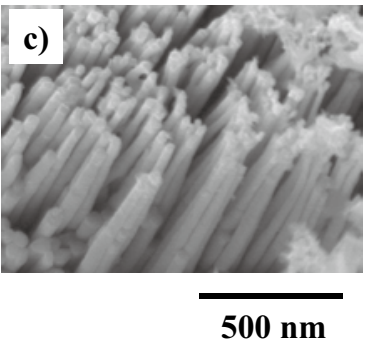

Fig. 7 SEM images of nickel nanopillars; a) DC galvanostatic electrolysis; b) $0.1 \mathrm{~Hz}$-hybrid electrolysis of AC and DC; c) $1000 \mathrm{~Hz}$-hybrid electrolysis of AC and DC. 
観察結果より算出した表面積は，1000 Hz の皮膜から得られ たナノピラーでニッケル平板の約 114 倍であり, 表面積に対 して低い電流值を示した。これは, ナノピラーが円錐状であ るため, 基質である $\left[\mathrm{Fe}(\mathrm{CN})_{6}\right]^{2+}$ および $\left[\mathrm{Fe}(\mathrm{CN})_{6}\right]^{3+}$ が根 元まで入り込み難いことが考えられる。また，高周波になる にしたがい, ピーク電流值が高くなる傾向が認められた。ピー ク電流值は次の Randles-Sevcik 式(3)によって表され ${ }^{18)}$,

$$
\begin{aligned}
& \mathrm{i}_{\mathrm{p}}=2.69 \times 10^{5} \mathrm{n}^{3 / 2} \mathrm{AD}^{1 / 2} \mathrm{Cv}^{1 / 2} \\
& \mathrm{i}_{\mathrm{p}} \text { : ピーク電流, } \mathrm{A} \text { : 電極面積, } \mathrm{D} \text { : 拡散係数, } \\
& \mathrm{C} \text { : 濃度, } \mathrm{v} \text { :掃引速度 }
\end{aligned}
$$

掃引速度の平方根に対してプロットしたときの傾きから拡 散係数 D が求められる。その結果を図 12 に示した。得られ たニッケルナノピラー集合体 a） $1000 \mathrm{~Hz}$, b) 直流定電流電解, c) $0.1 \mathrm{~Hz}$ を用いたグラフの傾きは, 平板 d) を用いたグラフ の傾きと比較すると, 明らかに大きくなっており, 拡散係数 の増大が認められた。これは, ナノピラー構造を有すること によって, 表面積とともに反応場が著しく増大したためと考 えられる。

\section{4. 結言}

(1)アノード酸化時に周波数を印加することで, 孔径や孔数と いった幾何学的構造が制御できることがわかった。また, 周波数が高くなるほど電解電圧が小さくなり, それにとも ない孔径は小さく，孔数は増加することがわかった。

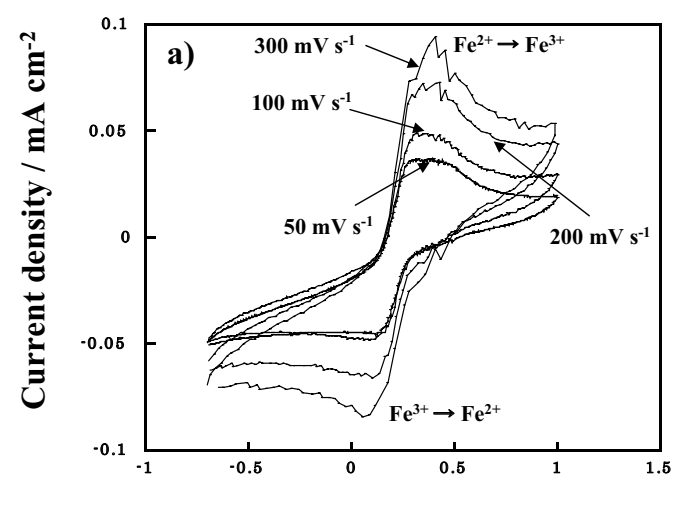

Potential / V vs. SCE

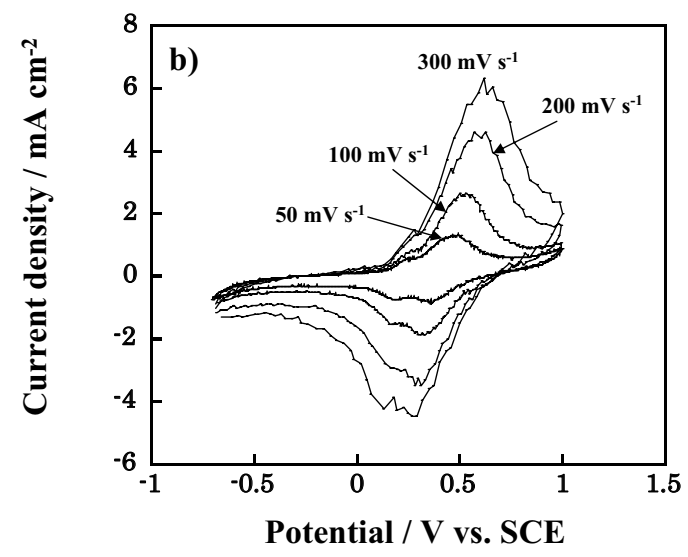

Fig. 10 Cyclic voltammogram of a) flat nickel electrode; b) $1000 \mathrm{~Hz}$-nickel nanopillars in an electrolyte containing $5 \mathrm{mM} \mathrm{K}_{3} \mathrm{Fe}(\mathrm{CN})_{6}$ and $0.5 \mathrm{M} \mathrm{Na}_{2} \mathrm{SO}_{4}$.
(2)アルミニウムアノード酸化膜をテンプレートとしてニッケ ルナノピラー集合体が簡便に得られ，50〜90 nm までの ピラー径制御に成功した。

(3)周波数を変化させたアノード酸化膜をテンプレートとする ことでナノピラーの表面構造が変化し，それにともなって 電極特性が変化することがわかった。具体的には, 高周波 数であるほど高いピーク電流值が得られるなど効果的なレ スポンスを得ることができた。

以上の結果より, 孔径を変化させたアルミニウムアノード 酸化膜をテンプレートとすることによって, ナノピラー径や 単位面積当たりの孔数を制御することが可能となった。すな わち, アルミニウムアノード酸化膜をテンプレートとした, ナノ構造物の作製制御や, センサ・電極の高性能化などへの 応用が期待される。

(Received November 30, 2009 ; Accepted April 12, 2010)

\section{文献}

1 ) 小柳光正; 次世代半導体メモリーの最新技術, p. 297 (株シーエ ムシー出版, 2009).

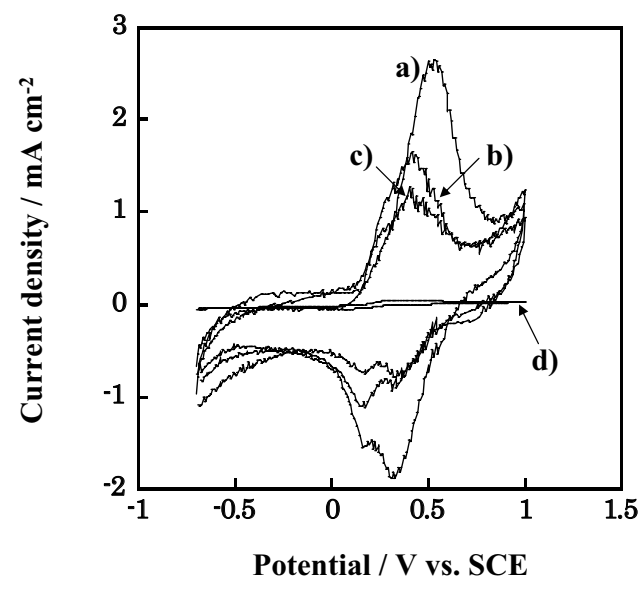

Fig. 11 Cyclic voltammogram under scan rate of $100 \mathrm{mV} \mathrm{s}^{-1}$ of nickel nanopillars with different frequency; a) $1000 \mathrm{~Hz}$; b) DC; c) $0.1 \mathrm{~Hz}$; d) flat nickel electrode.

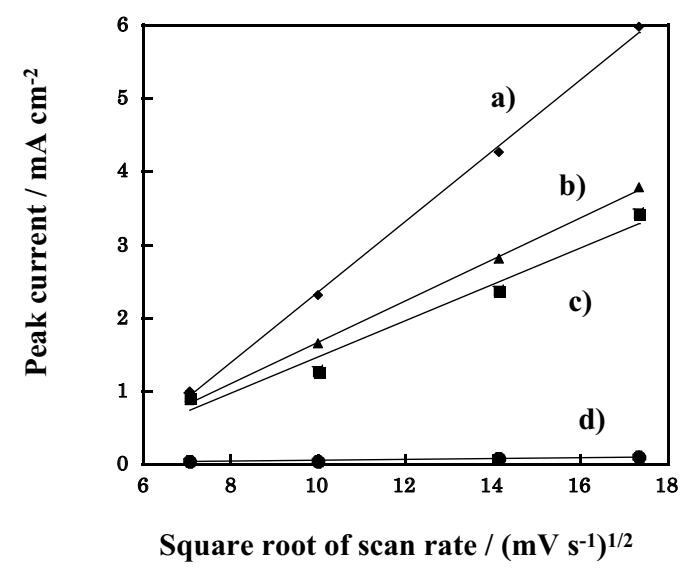

Fig. 12 Variation of the peak current with the square root of scan rate $(\mathrm{mV} / \mathrm{s})^{1 / 2}$ in nickel nanopillars and flat nickel electrode; a) $1000 \mathrm{~Hz}$; b) DC; c) $0.1 \mathrm{~Hz}$; d) flat nickel electrode. 
2) K. Sayama ; AIST today, 8, 10 (2008).

3 ) Z. Wang, Y. Su, H. Li ; Appl. Phys. A, 74, 563 (2002).

4 ) M. Gao, L. Dai, G. Wallace ; Electroanalysis, 15, 13 (2003).

5 ) J. Wang, M. Mustafa ; Analyst, 75, 2075 (2003).

6 ) J. Wang, M. Mustafa ; Analyst, 129, 1 (2004).

7 ) M. Yemini, M. Reches, J. Rishpon ; Nano Lett., 5, 183 (2003).

8 ) S. Bharathi, M. Nogami ; Analyst, 126, 1919 (2001).

9 ) 本間 格; 次世代自動車用高性能蓄電システム技術開発計画発 表会講演要旨集, p. 43 (NEDO, 2008).

10) K. Kurihara, T. Nakano, J. Tominaga, Y. Saito, H. Kato ; Plastics Science, 5, 70 (2008).
11) J. W. Park ; Nanotechnology, 17, 2631 (2006).

12) K. Lau, J. Bico, K. Teo ; Nano Lett., 3, 1701 (2003).

13）吉村長蔵; アルミニウムの化学と表面処理, p. 17 (欧文企画出 版社, 1985).

14）川合 慧; $\mathrm{A} 1$ の機能的アノード処理, p. 77 (槇出版, 2005).

15）安保正一; 高機能な酸化チタン光触媒, p. 97 (NTS, 2004).

16）藤野隆由; 特開2007-204831 (2007).

17）藤島 昭, 相沢益男, 井上 徹; 電気化学測定法, p. 209 (技報 堂出版社, 1988).

18）春山志郎; 表面技術者のための電気化学, p. 282 (丸善(侏), 2007). 